\title{
The English Sweat in Lübeck and North Germany, 1529
}

\author{
JOHN CHRISTIANSEN*
}

Only two of the epidemics of the English sweating sickness have been the subject of modern demographic studies. Robert Gottfried analysed the mortality of the 1485 epidemic by studying probated wills, and John Wylie and Ian Linn, and more recently Alan Dyer, analysed the 1551 epidemic on the basis of parish burial registers. ${ }^{1}$ The epidemic of the sweat in England in 1528, which is of special interest in the present context since in all probability it caused the epidemic on the European continent in 1529, has not been studied demographically, possibly because burial records did not exist before 1538 . Literary sources, however, seem to indicate that this epidemic was severe. In a letter of 30 June 1528, the French ambassador, Jean Du Bellay, wrote that 40,000 people had been affected by the disease in London, and 2,000 had died, and the descriptions in Raphael Holinshed's chronicle and in Grafton's chronicle leave no doubt that this epidemic took a heavy toll. ${ }^{2}$

Since no demographic analysis of the epidemic on the continent in 1529 has been carried out so far, this article focuses on the outbreak of the sweating sickness in north Germany and Schleswig-Holstein because the existence of testamentary records in Lübeck from the period makes such an analysis possible.

\section{Chroniclers' Accounts of the Epidemic in North Germany}

The first detailed description of the sweating sickness epidemic of 1529 on the continent was given by J F C Hecker, to whom most subsequent accounts of this outbreak refer. ${ }^{3}$ The disease was brought to Hamburg by a ship from England in July $1529,{ }^{4}$ and it spread along the Baltic coast, reaching Lübeck on 30 July, Stettin on 31 August,

\section{(C) John Christiansen 2009}

*John Christiansen, MD, MA, Bülowsvej 7A, DK-1870 Frederiksberg C, Denmark; e-mail: jochr@dadlnet.dk

\footnotetext{
${ }^{1} \mathrm{R}$ S Gottfried, 'Population, plague, and the sweating sickness: demographic movements in late fifteenth-century England', J. Br. Stud., 1977, 17 (1): 12-37; John A H Wylie and I J Linn, 'Observations upon the distribution and spread of the English sweating sickness (sudor anglicus) in Devon in 1551', Rep. Trans. Devon. Ass. Advancement. Sci., 1980, 112: 101-15; Alan Dyer, 'The English sweating sickness of 1551: an epidemic anatomized', Med. Hist., 1997, 41: 362-84.
}

\footnotetext{
${ }^{2}$ Charles Creighton, A history of epidemics in Britain from $A D 664$ to the extinction of the plague, 2 vols, Cambridge University Press, 1891, vol. 1, pp. 251-2; R Holinshed, Chronicles of England, Scotland, and Ireland, 6 vols, London, J Johnson, 1807-1808, vol. 3, pp. 735-6; Grafton's chronicle, or, History of England from the year 1189 to 1558 , 2 vols, London, J Johnson, et al., 1809, vol. 2, p. 412.

${ }^{3} \mathrm{~J}$ F C Hecker, The epidemics of the Middle Ages, transl. B G Babington, 3rd ed., London, Trübner, 1859, pp. 228-45.

${ }^{4}$ Reimarus Kock, Chronicle, in C G Gruner (comp.), Scriptores de sudore anglico superstites, Jena, F Maukius, 1847, pp. 443-4.
} 


\section{John Christiansen}

and Danzig on 1 September. It moved north to Schleswig-Holstein and Denmark, reaching even Sweden and Norway, and also the south of Germany where Strasbourg, Frankfurt, Cologne, Marburg and Göttingen were assailed in September. ${ }^{5}$ Recently John Flood has given a detailed description of the spread of the disease on the continent and he, like Hecker, states that it claimed 1,100 victims in Hamburg in the course of four to five weeks; both use Nicolaus Staphorst as their source. ${ }^{6}$

The Hamburg Chronicle published by Johann Lappenberg in 1861 also gives the figure of 1,100 dead in one month in Hamburg, and the Chronicon der Wendischen Städte referred to by Peter Hanssen claims a death toll of 1,000 in four weeks (the population of Hamburg around 1500 was about 20,000). ${ }^{7}$ The outbreak of the sweating sickness in north Germany is also mentioned in the minutes of the Lübeck Cathedral Chapter. For the year 1526 they note that "in summer there was a great plague [eine grosse pestilenz] in Hamburg", but the entry for 1529 describing another serious epidemic uses the term "pestis suderosa", a sweating plague. The description of the symptoms leaves no doubt that it was the sweating sickness. ${ }^{8}$

It is difficult to determine which is the primary source of information on mortality during the sweat in Hamburg since exact dating of the chronicles is not possible. The earliest seems to be a chronicle found by G C F Lisch dated 1532, indicating it was written at least three years after the epidemic. ${ }^{9}$ None of the chronicles on the continental outbreaks of sweating sickness collected by $\mathrm{C} \mathrm{G}$ Gruner mentions mortality figures in Hamburg. ${ }^{10}$ Lisch's work on the sweating sickness includes an interesting report from the physician Rembertus Giltzheim to the Grand Duke of Mecklenburg. ${ }^{11}$ Giltzheim was a medical doctor and in 1515 professor of medicine at the university of Rostock. Around 1512 he was appointed physician-in-ordinary to the Duke of Mecklenburg, and in 1529 he stayed in Lübeck from where he sent his report. He gives a precise description of the symptoms and of the course of the disease as well as a detailed account of the various remedies and measures used for treatment. The only demographic information

\footnotetext{
${ }^{5}$ Regimen vitebergium, in Gruner (comp.), op. cit., note 4 above, pp. 231-5.

${ }^{6}$ John L Flood, " "Safer on the battlefield than in the city": England, the "sweating sickness", and the continent', Renaissance Studies, 2003, 17: 147-76, p. 156; Nicolaus Staphorst, Historia ecclesiae Hamburgensis diplomatica, 5 vols, Hamburg, Theodor Christoph Felginern, 1723-1731, 1729, vol. 2, pp. 84-5. Staphorst writes: “... so dat van Jacobi beth tho Hemmelfahrt-Marien Dage weren verstorven by 1100 Minschen ...". Staphorst gives no reference for his source of this information.

${ }^{7} \mathrm{~J}$ M Lappenberg (ed.), Hamburgische Chroniken in niedersächsischer Sprache, Wiesbaden, Martin Sändig, 1861; Peter Hanssen, Geschichte der Epidemien bei Menschen und Tieren im Norden, Glückstadt, J J Augustin, 1925, p. 61. For the population of Hamburg, see Franklin Kopitzsch and Daniel Tilgner (eds), Hamburg Lexikon, Hamburg, Ellert \& Richter, 2005, p. 67.
}

\footnotetext{
${ }^{8}$ Jürgen Hartwig Ibs, Die Pest in SchleswigHolstein von 1350 bis 1547/48, Frankfurt am Main, Peter Lang, 1994, p. 126.

${ }^{9}$ G C F Lisch, 'Die Schweißsucht in Meklenburg im Jahre 1529', in G C F Lisch (ed.), Jahrbücher des Vereins für mecklenburgische Geschichte und Altertumskunde, Schwerin, 1838, pp. 60-83, p. 61, ftn 2: "In dem suluenjare sunte Jacobs dach tho mytzamer vorhoff sick eyne nye kranckheit, de sweytszuke genometh, und de dar innebeuellen most sick befruchten, in XXIIII stunden doeth edder leuendich tosyn; und dar storuen binnen hamborch in IIII efften vyff weken meer den dusent mynschen unde sesuke toch vorth auer alle didesche landt alsze eyn blixen, szo dat dat folck szer erschrockenn wardth."

${ }^{10}$ Gruner (comp.), op. cit., note 4 above.

${ }^{11}$ Lisch, 'Die Schweißsucht', op. cit., note 9 above, pp. 60-8.
} 
included is that, in Lübeck, no children died of the sweat and that the victims were mostly men and women aged between sixteen and sixty. It is obvious from the report that the population of the city was panic-stricken and that Giltzheim considered the epidemic to be very serious, but unfortunately he gives no estimate of the number of people afflicted with or dead of the disease.

Written twenty-three years before John Caius published his Boke or counseill against the disease called the sweate, Giltzheim's account of the disease on the continent may be credited with the same importance as Caius' description of the disease in England. ${ }^{12}$ Giltzheim's title was Underricht wie man sich vor der schweissenden krankheit waren und darynne halten soll (A Counsel on how One should take Precautions against the Sweating Sickness and Behave during It)—which is very close to that of Caius. The description of the symptoms and course of the disease, as well as recommendations for treatment, are almost identical in the two publications, leaving no doubt that they are writing about the same sickness. Although Giltzheim gives no information on mortality in Lübeck, the fact that he is able to provide information on the course of the disease in different age groups must mean that he observed a large number of patients. It should be noted that his report was dated 8 August, a month before the publication of the other detailed German description of the disease by Euricius Cordus, a physician and professor of medicine in Marburg, who in September 1529 published a comprehensive exposition of the sweating sickness. ${ }^{13}$

Lisch also refers to an order in the ducal archives from the chancellor, von Schöneich, to Jürgen Wolder, the bailiff in Grevismühlen, according to whom many people died of the sweating sickness in Lübeck, Wismar and other places. For this reason von Schöneich's order prohibited any traffic between the monastery at Rhena and these infected towns. ${ }^{14}$

There are two other documents in the Mecklenburg archive that give the number of victims of the sweating sickness. One is a report to the Duke from Johannes Smeth, the land steward on the estate of Boizenburg, which states that in Hamburg and Lüneburg many died of the disease within a few days, and that between 10 and 13 August sixty people died in Boizenburg. He adds, furthermore, that he and the bailiff have closed the ducal house, keeping on only the porter, the cook and a maid. The other document is a contemporary Low German chronicle from the convent in Ribnitz in the eastern part of Mecklenburg written by Lambertus Slagghert, a teacher at the convent, according to whom 25 nuns and 7 employees were struck by the disease but none died. ${ }^{15}$ Lisch

\footnotetext{
${ }^{12}$ John Caius, $A$ boke or counseill against the disease commonly called the sweate, London, Richard Grafton, 1552.

${ }^{13}$ Euricius Cordus, Ain Regiment, in Gruner (comp.), op. cit., note 4 above, pp. 75-92.

${ }^{14}$ Lisch, 'Die Schweißsucht', op. cit., note 9 above, p. 70 .

${ }^{15}$ Ibid, p. 73. It is surprising that none of 32 infected people died but from the epidemics in England it is well known that mortality varied considerably between different regions, see Dyer (op. cit., note 1 above, pp. 379-80), and Wylie and Linn (op. cit., note 1 above, p. 105). Also the approach to
}

treatment of the disease may have varied between different regions. Dehydration was probably the main reason for the rapid death within twenty-four hours and since many doctors, including John Caius, advocated fluid restriction, the treatment in itself may have increased mortality. A number of contemporary continental doctors supported fluid restriction, among them Anthonium Brelochs, Ein kurtzer gegründter undterricht, unnd erklerung einer geschwinden, und überscharpffen seuchten, yetzo von vielen der Englisch schwayss, aber von den Alten das Pestilentzisch fieber genant, in Gruner (comp.), op. cit. note 4 above, pp. 123-46, on p.131, and Johann 


\section{John Christiansen}

finishes his essay on the sweating sickness by saying that in this year (1529) no students were matriculated at the university of Rostock, which probably means that fear of the sickness kept them away.

As the epidemic spread eastwards along the Baltic coast, Stettin, Greifswald and Danzig were seriously affected, with a death toll in the latter town of 3,000 to 6,000 according to unidentified chronicles referred to by Bernhard Lersch. ${ }^{16}$ The chroniclers give no mortality figures for Lübeck, but an impression of the severity with which they considered the outbreak is indicated by Jakob Hanssen and Heinrich Wolf, who wrote: "It killed unbelievably many in a short time." ${ }^{17}$ This should be viewed in the light of information given on the preceding pages on the mortality caused by the plague in Lübeck where the authors claim mortality figures of 10,000 in 1438 and 17,000 in 1564 out of a population which in the middle of the sixteenth century was about $25,000 .{ }^{18}$ Even though these figures are probably exaggerated, the words "unbelievably many" in this context must mean that mortality from the sweat was very high indeed.

\section{The Epidemic of 1529 in the Duchies of Schleswig and Holstein}

A number of chronicles refer specifically to the outbreak of the sweat in the duchies of Schleswig and Holstein. In 1529 Schleswig was part of the Danish crown, the Danish king being Duke of Holstein and, as a result of a personal union between the two duchies, also feudal overlord in Holstein although this duchy was a fief of the GermanRoman empire. However, due to their close proximity to Lübeck and Hamburg, a similar course of the epidemic could be expected in the duchies. (Lübeck is situated directly on the border with Holstein, and the district of modern Hamburg called Altona was in 1529 an independent town in Holstein.)

Neocorus (Johann Adolfi) writes in his chronicle on the Dithmarsch region that there was an outbreak of the "Schwedsuct edder der Englische Suct" in 1529, from which many young people died. ${ }^{19}$ Hanssen and Wolf also provide the same information without any indication of their source which, however, could very well be Neocorus. ${ }^{20}$ The town of Schleswig was, according to August Sach, badly affected by the disease, which caused great mortality. He comments that the death rate was so high that the poor could not

Hellwetter (Vor die Engelische krnackheyt die Schweysssucht, in Gruner (comp.), op. cit., note 4 above, pp. 147-52, on p. 152), while others, for example Euricius Cordis, supported fluid intake (op. cit., note 13 above, pp. 80, 87). Cordis was professor of medicine in Marburg, where according to Luther about 50 were hit by the disease but only one or two died (Martin Luther, Briefwechsel, Weimar, Hermann Böhlaus, 1934, vol. 5, p. 154). If Euricius Cordis's attitude to fluid intake was generally accepted in Marburg, it could explain the low mortality of the disease in this town.

${ }^{16}$ B M Lersch, Geschichte der Volksseuchen, Berlin, S Karger, 1896, pp. 215-20.
17 “... . und tödete in kurzer Zeit unglaublich Viele”, J Hanssen and H Wolf, Chronik des Landes Dithmarschen, Hamburg, Langhoff, 1833, pp. 422-3.

${ }^{18}$ W-D Hauschild, 'Frühe Neuzeit und Reformation: das Ende der Grossmachtstellung und die Neuorientierung der Stadtgemeinschaft', in A Grassmann (ed.), Lübeckische Geschichte, Lübeck, Schmidt-Röhmhild, 1989, pp. 341-432.

${ }^{19}$ Johann Adolfi (genannt Neocorus), Chronik des Landes Dithmarschen, ed. F E Dahlmann, Kiel, Universitetsbuchhandlung, 1827, p. 69.

${ }^{20}$ Hanssen and Wolf, op. cit., note 17 above, p. 423. 


\section{The English Sweat in Lübeck and North Germany, 1529}

afford the large number of burials. ${ }^{21}$ Sach does not refer directly to his sources but they appear to be contemporary chronicles. Additionally, in his history of Schleswig, Johannes Schröder mentions the cruel epidemic of the "Schweisskrankheit", referring to a contemporary source called Das braune Rathsbuch (The Brown Council Book). ${ }^{22}$ In the Schleswig archives a note mentions that although the epidemic was severe, the chronicler considers the course of the disease in Schleswig to have been milder than that in other northern German towns. ${ }^{23}$

Finally, there is evidence that the Holstein town of Eckernförde was also ravaged by the sweat. Hanssen writes in his Versuch einer Chronik von Eckernförde: "At this time, particularly in the year 1529, a malignant sweating epidemic, also called sudor anglicus, killed many people." ${ }^{24}$ From the accounts in these chronicles, it seems fair to conclude that the epidemic of the sweating sickness in north Germany, including Lübeck, and in Schleswig-Holstein caused severe depredation among the population.

In order to see if the chroniclers' claim of the course of the sweating sickness in north Germany and Schleswig-Holstein could be supported by numerical evidence, I carried out a testamentary analysis based on registered wills in Lübeck during the period $1520-1534$.

\section{Methodological Considerations}

In his study on the demographic effect of plague and the sweating sickness in England, Gottfried presents a thorough discussion of the methodological problems in connection with the use of testamentary records for demographic purposes. ${ }^{25}$ An important source of bias is differences in the social structure of a given society-a rich society will produce a higher number of wills than a poor one, as clearly shown in a study from

\footnotetext{
${ }^{21}$ August Sach, Geschichte der Stadt Schleswig nach urkundlichen Quellen, Schleswig, Julius Bergas, 1875 , p. 153 ( " 1529 raffte die svedtsyke eine so grosse Zahl von Menschen hin, dass zur beerdigung der ärmeren Einwohner die nöthigen Gelder fehlten").

${ }^{22}$ Johannes von Schröder, Geschichte und Beschreibung der Stadt Schleswig, Schleswig, Königl. Taubstummen-Institut zu Schleswig, 1827, p. 333.

${ }^{23}$ Gemeinschaftsarchiv, Schleswig, Abt. 2, nr. 95: Der Stadt Schleswigk Schotell Boeck 1524-1588. p. XVII: "Des 29. Jahres. . . einigen Falles durchlief die ganze deutsche Nation die erschreckliche Seuche Schwitzseuche, aus England ursprünglich her gekommen, die darein befallen starben binnen 24 Stunden, sobald aber von den davon befallenen die 24 Stunden überlebten, die konnten sofort essen, trinken, arbeiten, gehen, reisen,stehen was die wollten, die hatten solche unermessliche Hitze und schwitzten die davon Befallenen, dass menschlicher
}

\begin{abstract}
Vernunft es unmöglich gewesen, dass jene Menschen davon konnten da Leben werhalten.... Und obwohl jetzt in den benachbarten Landen und Städten in Lübeck, Rostock, Hamburg, Bremen und weiterhin wo auch in diesen Landen, Städten und Flecken ein erschrechlich eiliges oderschnelles Hinfallen der Menschen gewesen ist, hat der liebe Gott doch die Stadt, vor allen anderen gnädig und väterlich beschutzt, und obwohl auch viele hier in dieser schrechlichen Plage befallen so ist doch hier nicht mehr als unser Pastor Marquardus Schuldrup der gelehrte Mann und fleissige Prediger gestorben ...”.

24 "Um diese Zeit zumal im Jahre 1529 raffte eine bösartige Seuche-Sweetsüke, auch Sudor Anglicus genannt,- - viele Menschen hin"; C G Hanssen, Versuch einer Chronik von Eckernförde, Kiel, Königl. Schulbuchdruckerei, 1833, p. 15. Hanssen's source is given in ftn 30 on p.15: Noodts Beitr. 2. vol. p. 272.

${ }^{25}$ Gottfried, op. cit., note 1 above, pp. $14-17$.
\end{abstract}




\section{John Christiansen}

Avignon where the ratio of merchants to craftsmen increased during the late Middle Ages, resulting in a marked rise in the number of registered wills. ${ }^{26}$ In Lübeck, wills were registered in the city's archives and date from as far back as 1278. Jürgen Ibs has published a demographic analysis of the plague epidemics in Lübeck during the years $1462-82$ based on the wills from this period. ${ }^{27}$ According to Ashaver von Brandt, it was common practice among the citizens of Lübeck to draw up a will, which seems logical since this important Hanseatic town with its extensive international trade was the home of a large number of wealthy merchants as well as many seamen. The proportion of the population that actually did make a will is unknown, but since, according to Brandt, this required the presence of two aldermen, who could be substituted by two respectable citizens if the value of the fortune did not exceed 10 silver marks, this seems to indicate that it was not only the rich who made wills.

The wills, which always show the date of registration by the city council, usually begin with an invocation followed by a list of bequests to the church and charitable institutions, and lastly those to individual persons, including the testator's family. It is always stated that the testator is mentally healthy, undoubtedly to ensure the validity of the document, whereas somatic disease is revealed by the word "krank". Diagnoses are never mentioned. Before 1354 the wills were always written in Latin, but subsequently German took over, and in the years under study all the wills are written in German.

In contrast to the conditions described by Gottfried in his testamentary analysis of the sweat mortality during the 1485 epidemic in England, ${ }^{28}$ there are no probate dates for the wills in Lübeck, which means that we do not know when the testator died. Additionally, there are no burial registers (Beerdigungsisten) for the year 1529, and account books from the churches (St Mary, St Peter, St James and St Aegidien) where payment for burials were registered, do not exist before 1531. In an attempt to establish a day of death of the testators who drew up wills in July and August 1529, all sixteenth-century registers of Lübeck citizens have been consulted. ${ }^{29}$ However, the name of only one of the testators (an alderman) was retrieved.

The only indication of death having taken place shortly after registration of a will is a commonly used clause relating to withdrawal of the document (Widerrufsvorbehalt or Widderrope). It is reasonable to assume that this clause would be used when people feared an epidemic or warfare and that the will would be withdrawn once the danger had passed and the testator had survived. Only 5 out of 19 wills from July and August 1529 do not contain this clause, which may indicate that the majority of the testators did not survive the epidemic and since, according to all contemporary sources, death

\footnotetext{
${ }^{26} \mathrm{~J}$ Chiffoleau, 'Les testaments provençaux et comtadins à la fin du moyen âge', in Paolo Brezzi, Egmont Lee (eds), Sources of social history. Private acts of the late middle ages, Toronto, Pontifical Institute of Mediaeval Studies, 1984, pp. 131-52.

27 Ibs, op. cit., note 8 above, pp. 117-123. The wills in Lübeck have been published only for the period 1278-1363 by Ashaver von Brandt (Regesten der Lübecker Bürgertestamente des Mittelalters,
}

Lübeck, Max Schmidt-Röhmild, vol. 1, 1964; vol. 2, 1973). The present study is based on registered wills from the period 1520-1535 preserved in the Archiv der Hansestadt Lübeck.

${ }^{28}$ Gottfried, op. cit., note 1 above, p. 16.

${ }^{29}$ Lübeckische Geschlechter, Archive number HS $17^{1}$. Personenregister "Schnobel". Archive number HS $817^{2}$. Personenkartei (card index of Lübeck citizens). 
from the sweat invariably occurred within twenty-four hours, the dates of death must have been very close to those of will registration.

Finally, a few remarks should be made concerning the crisis mortality or "crisis mortality rate" (CMR). This is defined as the ratio of deaths in a given year to the mean death rate for the adjacent years, often five to ten years. This concept is used to describe the impact of an epidemic on mortality in a given population compared with "normal" mortality. In distinguishing a crisis from random fluctuations it is obviously important to take account of the variability of the frequency with which wills are drawn up. These fluctuations will of course be greater in a small community than in a large one.

In their analysis of mortality during the epidemic of sweating sickness in 1551, Wylie and Linn used a five-year period (1549-53) as a basis for an evaluation of crisis mortality. ${ }^{30}$ They chose a CMR of 3 (the number of deaths should be 3 times higher in 1551 than the mean of the adjacent four years) as the lower limit for crisis mortality. So too did Paul Slack in his study of plague in Devon in 1546-47, whereas in his work on the sweat in 1551, he considered a factor of 2 as an indication of crisis mortality. ${ }^{31}$ It appears that although it may be an advantage to use a statistic like CMR to describe a significantly increased mortality, there is no universal agreement on the definition and limiting value of this parameter. A comprehensive discussion of the problems relating to identifying crisis mortality has been provided by E A Wrigley and R S Schofield. ${ }^{32}$

With regard to the sweating sickness there is a problem in using CMR since this parameter is based on a yearly death rate. As pointed out by Dyer, the distinguishing feature of the sweat is not the total number of people killed, which is sometimes relatively modest, but the concentration of burials over a very short period of time, characteristically a week or ten days. ${ }^{33}$ This means that none or only a modest elevation in CMR may be interpreted as showing no increased mortality caused by the sweat. However, a significant increase in CMR, provided other causes are excluded, will be an indication of increased mortality from the disease in spite of its short duration.

\section{Analysis of Registered Wills from Lübeck in the Period 1520-1534}

The Archiv der Hansestadt Lübeck contains 272 wills from the period 1520-34. The reason for starting the analysis in 1520 is that there was an epidemic of plague in Lübeck in $1521,{ }^{34}$ which makes it possible to include a year of plague for comparison with the year of the sweat, 1529. There may also have been an epidemic of plague in Lübeck in 1526-27 since Hamburg in all probability was struck by this disease in

\footnotetext{
${ }^{30}$ Wylie and Linn, op. cit., note 1 above pp.104-5.

${ }^{31}$ Paul Slack, The impact of plague in Tudor and Stuart England, London, Routledge \& Kegan Paul, 1985, pp. 88, 26.
}

\footnotetext{
${ }^{32}$ E A Wrigley and R S Schofield, The population history of England 1541-1871, London, Edward Arnold, 1981, pp. 646-93.

${ }^{33}$ Dyer, op. cit., note 1 above, p. 364.

${ }^{34}$ Ibs, op. cit., note 8 above, p. 125.
} 


\section{John Christiansen}

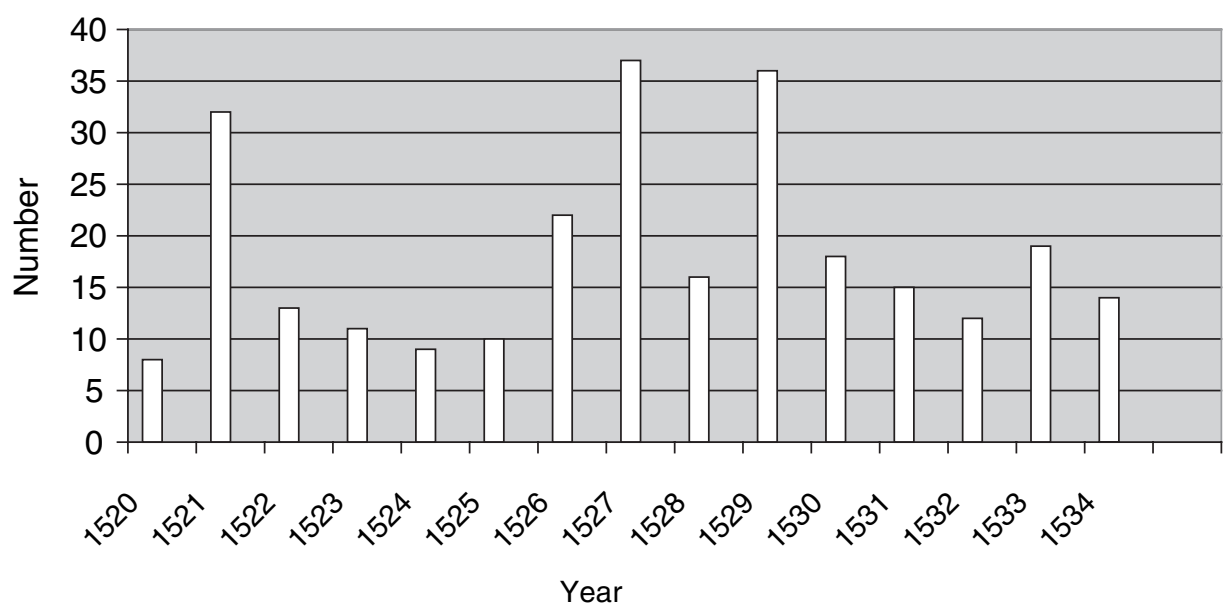

Figure 1: Wills in Lübeck 1520-1534.

$1526 .{ }^{35}$ As shown in Figure 1, there was a marked increase in the number of wills in 1527 and 1529 (37 and 36 respectively), more than twice that of the other years, with the exception of 1521 and 1526. Consequently the number of wills in 1529 may indicate that there was an epidemic in the town that year, which is also true for 1527, when the plague in all probability was the cause (the epidemic in 1527 was called pestis by the chroniclers but that of 1529 pestis suderosa) ${ }^{36}$ Comparison of the number of wills in 1529 with the mean of the fifteen-year period, excluding the plague year of 1521 but including 1527, results in a CMR of 2.29. If the other "crisis" year of 1527 is excluded, the CMR increases to 2.59. If this figure is related to Slack's study of the 1551 epidemic of the sweat in England, where a CMR of 2 for the whole year is considered "significant", ${ }^{37}$ there was definitely a crisis mortality in Lübeck in 1529. It is interesting, that the CMR for 1529 in Lübeck was as great as that for the plague year 1521 (2.59 versus 2.30$)$ and for 1527 , when there was probably a plague epidemic (2.59 versus 2.66), which must mean that the demographic effect of the sweat in 1529 was as great as the effect of the plague epidemics in the adjacent years.

A closer analysis of the distribution of wills over the years 1529 and 1527 reveals some interesting differences (Figure 2). In 1529 there is a marked peak in the testamentary mortality in August, and an analysis of the dates of issue shows that 15 of the 17 wills were made out between 1 and 5 August-an almost panicky frequency. From the last part of August into September, the number of wills registered fell to the normal level. In the last four months of the year only 4 wills were registered, compared with 12

${ }^{35}$ Ibid., p. 207.

${ }^{37}$ Slack, op. cit., note 31 above, p. 26.

${ }^{36}$ Ibid., p. 126 , ftn 225. 


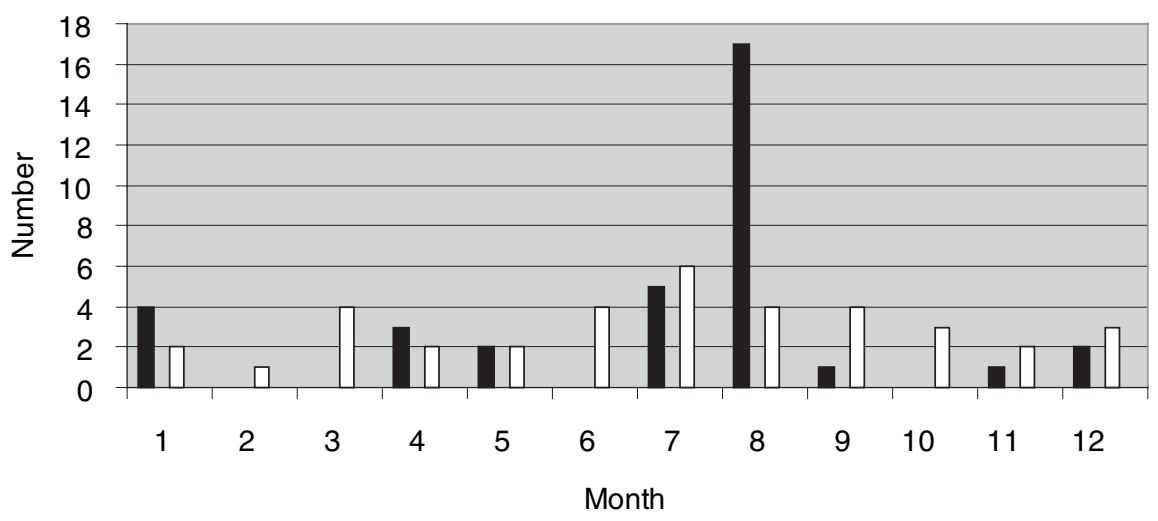

Figure 2: Wills in Lübeck 1529 (black) and 1527 (white).

on a yearly basis which must be considered the normal rate according to Figure 1. An analysis of the monthly number of deaths according to the Poisson distribution ${ }^{38}$ shows that the probability of 17 wills being made in August 1529 as a result of random variation is extremely low. ${ }^{39}$ In brief, there was an intense but short-lived incentive to draw up wills around 1 August which corresponds well to the time when, according to the chroniclers, the sweat reached Lübeck.

The analysis of testamentary records from Lübeck between 1520 and 1534 is consistent with the chroniclers' claim that the sweating sickness reached the city around 1 August in 1529 and that the epidemic was severe, since the number of wills issued in that month reached "crisis mortality" values, resulting in a total number of wills for the whole year that equalled that of the years of plague. This marked increase in registered wills in 1529 was due solely to an extraordinary number being registered in one week in August. This accords with Dyer's statement that the distinguishing feature of the sweat is not necessarily the total number of people killed, but the concentration of death over a very short period of time.

From Schleswig and Holstein the sweat spread north to Denmark, Norway and Sweden. Since registered wills or burial registers from this period do not exist in Scandinavia it is not possible to give a valid estimate of the demographic impact of the sweat. Chronicles and especially reports from the Danish king's provincial governors in Norway and Scania, south Sweden (both were in 1529 part of the Danish crown), clearly show that people were alarmed by the epidemic and that it carried a high

\footnotetext{
${ }^{38}$ Documenta Geigy: scientific tables, Basel, J R Geigy, 1962, pp. 186-8.

${ }^{39}$ The mean number of issued wills per month in the years $1520-1534$ was 1.5 . The probability that any month contains $d$. wills is $\frac{\mathrm{e}^{-\lambda} \lambda^{\mathrm{d}}}{\mathrm{d} \text { ! }}$ which for $d=5$
}

would be 0.001 . If more than 5 deaths are observed in a month the assumption that this has happened by chance can be rejected quite convincingly. The probability of observing 17 deaths in one month is extremely small. 


\section{John Christiansen}

mortality. The governor in Norway complained to the king that no workers were available since this "pestilence" had wiped out most of the workforce. ${ }^{40}$

In conclusion, according to literary sources, the course of the epidemic of sweating sickness in 1529 seems to have been severe in north Germany and Schleswig-Holstein, a hypothesis which is strongly supported by testamentary analysis from Lübeck.

${ }^{40}$ John Christiansen; 'Den engelske svedesyge. En analyse af epidemien i Danmark i 1529' (with an English summary), Historisk Tidsskrift, 2005, 105: 80-96. 